7. Malas Mahmoud B. Trends in Incident Hemodialysis Access and Mortality / Mahmoud B. Malas [et all.] // JAMA Surg. - 2015. - Vol.150 ( 5) - P. 441-448.

8. Renal Association Clinical Practice Guideline on Vascular Access for Haemodialysis. - Nephron Clin Pract. - 2011. - 118 (Suppl 1). - p. 225-240.

9. Summary of clinical practice guidelines for vascular access for haemodialysis. - Transplant. - 2010. 25(5). - p. - 1596-60.

10. Trends in US Vascular Access Use, Patient Preferences, and Related Practices: An Update From the US DOPPS Practice Monitor With
International Comparisons / Ronald L. Pisoni [et all.] // American Journal of Kidney Diseases 2015. - Vol.65 - P. 905-915.

11. U.S. Renal Data System, USRDS 2013 Annual Data Report: Atlas of Chronic Kidney Disease and End-Stage Renal Disease in the United States, National Institutes of Health, National Institute of Diabetes and Digestive and Kidney Diseases, Bethesda, MD, 2013. [Електронний ресурс]. Доступ http://www.usrds.org/2013/view/Default. aspx.

Надійшла до редакції 30.08.2016 Прийнята до друку 07.09.2016

(C) Fomina S., 2016

УДК 616.611-002-008.6-053.2

SVITLANA FOMINA

\title{
PREDICTION OF UNFAVORABLE COURSE OF NEPHROTIC SYNDROME IN CHILDREN: THE MULTIMARKER PARALLEL CASCADE SYSTEM СВЕТЛАНА ФОМИНА
}

\section{ПРОГНОЗИРОВАНИЕ НЕБЛАГОПРИЯТНОГО ТЕЧЕНИЯ НЕФРОТИЧЕСКОГО СИНДРОМА У ДЕТЕЙ: МУЛЬТИМАРКЕРНАЯ ПАРАЛЛЕЛЬНАЯ КАСКАЛНАЯ СИСТЕМА}

State Institution "Institute of nephrology of NAMS of Ukraine”

ГУ «Институт нефрологи НАМН Украины»

Keywords: Renoscintigraphy, Indirect Renangiography, urine N-Acethyl- $\beta$-D-Glucosaminidase, urine $\beta$-Galactosidase, Prognosis, Likelihood Ratio.

Ключевые слова: реносцинтиграфия, непрямая реноангиография, $N$-ацетил- $\beta$-D-глюкозаминидаза мочи, $\beta$-галактозидаза мочи, прогноз, отношение правдоподобия.

Resume. The aim of study was to investigate the possibility of using the results of different diagnostic tests in children with nephrotic syndrome (NS) as prognostic markers during disease course.

Materials and methods. The operating characteristics of values derived in dynamic renoscintigraphy and indirect renangiography with $99 \mathrm{~m} T \mathrm{~T}$-DTPA, static renoscintigraphy with $99 \mathrm{~m}$ Tc-phosphate, levels of urine renospecific enzymes ( $N$-acethyl- $\beta$-D-glucosaminidase and $\beta$-galactosidase) were estimated in 480 NS children depending on disease activity.

Results. Different levels of prognostic value for studied parameters were confirmed depend of NS outcome.

Conclusion. Renoscintigraphy indexes and urine renospecific enzymes activity levels should be used as markers of the progression in NS children with the glance to optimal terms of studies' conduction and range parameters. The multimarker parallel cascade System for prediction of unfavorable NS course has been initiated. This System can be regarded as the start of a new strategic goal for determination of relevant unfavorable disease course parameters in any branch of medicine.

Резюме. Цель исследования: изучить возможность использования результатов разных диагностических тестов у детей с нефротическим синдромом (HC) в процессе наблюдения в качестве прогностических маркеров.

Материалы и методы. Операционные характеристики показателей, полученных при проведении динамической реносцинтиграфии и непрямой ренангиографии с $99 \mathrm{mTc}$-DTPA, статической реносцинтиграфии $c$ $99 m T c$-phosphate, определении уровней реноспецифических ферментов мочи (N-ацетил- - D-глюкозаминидазы и -галактозтидазы), были расчитаны у 480 детей с НС с учетом активности заболевания.

Результаты. Разные уровни значимости для прогноза изучаемых параметров подтверждены в зависимости от исходов $H C$.

Заключение. Показатели реносиинтиграфии и активность реноспецифических ферментов мочи могут быть использованы в качестве маркеров прогрессирования НС у детей с учетом оптимальных сроков проведения исследования и диапазонов показателей. Инициировано создание Системы мультимаркерного параллельного каскадного

Фомина Светлана Петровна прогнозирования неблагоприятного течения НС, котоsfomina@meta.ua рую можсно рассматривать как начало новой стратегии определения корректных неблагоприятных параметров течения заболевания в любой области медицины. 
INTRODUCTION. Nephrotic syndrome (NS) has a controversial prognosis and a wide range of results after long-term therapy [8]. The disease onset and duration is a multifactor process, and the association between disease features and their dependence degree is almost impossible to establish definitely. A lot of methods and tests are using for NS prediction $[9,10]$. The interpretation of their results is complicated by the variability of clinical situations and the necessity to repeat the tests in time for establish the determined special vector of prognosis. Moreover markers of prognosis are often replaced by markers of condition. Availability or preference of different patterns in such cases indicate a disease stage or its severity but not possible direction of its duration and outcome. The optimal prognostic markers get from the tests which are reliable, repeatable and have corresponding operating characteristics [7]. Test results are effective for prediction even if its sensitivity and specificity values are moderate $(60-70 \%)$ in the case when the likelihood ratio is calculated [9]. This ratio can display the risk of the disease or the risk of disease progression based on the aim of study. The risk of disease (or its progression) is twice higher in subjects with patterns than without it in the case LR positive result of test $(\mathrm{LR}+) 2.00$; the studied factor has not the prognostic value at LR+1.00; LR negative result (LR-) has an opposite meaning - absence of signs increases the risk of events.

THE AIM of study was to investigate the possibility of using the renoscintigraphy (RSG) parameters and the detection of urine renospecific enzymes activity as markers of unfavorable disease course in children with NS

MATERIALS AND METHODS. Four hundred and eighty nephrotic children (age from five to 15 years) were studied in active stage of disease (stage 1: before prednisolone treatment; stage 2: in 10 weeks of therapy; stage 3: on tapering treatment period 6-9 months) and up to 1.5-3 years of follow up (stage 4) in years 19862011 [2]. NS outcome was assessed five years after treatment withdrawal as remission or disease progression with reduced renal function (Chronic Kidney Disease, stage 3-5: CKD 3-5) [3, 6].

RSG dynamic with 99mTc-DTPA in combination with indirect renal angiography (IRAG) and static RSG with $99 \mathrm{mTc}$-phosphate were conducted during the observation period of at least two times in each patient. We examined the indexes: Glomerular Filtration Rate (GFR, ml/ $\mathrm{min}$ ), arterial flow duration ( $\mathrm{Ta}, \mathrm{sec}$ ), venous flow duration $(\mathrm{Tv}, \mathrm{sec})$, phosphate fixation after 60 minutes (\%) [5].

The urine activity values of two renospecific enzymes (N-acethyl- $\beta$-D-glucosaminidase - uNAG, $\beta$-galactosidase - $\mathrm{u} \beta$-Gal, $\mu \mathrm{mol} /$ hour/creatinine mmol) were estimated in 209 nephrotic children an additional in years 1991-2011 [3, 4].

Variables were reported as Me $(\mathrm{P} 25 ; \mathrm{P} 75)$. Eighteen children without kidney disease were included as controls: GFR $116(110 ; 128)$, Ta $6(6 ; 6)$, Tv $5(5 ; 5)$, phosphate fixation $2.2(2.0 ; 2.5)$, uNAG $10.2(8.8 ; 13.3)$, $\mathrm{u} \beta-$ Gal 10.4 (5.9;13.2).

The intervals of these parameters on the different NS stage were observed in patients depend on disease course, and the ranges of them in group with confirmed further CKD 3-5 were identified. The operating characteristics including LR+ and LR- were estimated for potential use of these intervals as the surrogate endpoints of NS outcome and the prognostic markers [7].

RESULTS. RSG analysis showed that likelihood of NS progression increased while reducing GFR $<60$ and phosphate fixation $<2.5$ in the disease active stage before treatment (stage 1; LR- 2.48 and LR- 4.28, respectively); GFR $<80$ and $\mathrm{Tv} \geq 7$ in 8-10 weeks of therapy (stage 2; LR1.77 and $\mathrm{LR}+1.94$, respectively); GFR $<90, \mathrm{Ta} \geq 8$, phosphate fixation $\geq 5.5$ on tapering treatment period (stage 3; LR- 2.23, LR + 1.86 and LR+ 2.36, respectively); GFR $<90$, $\mathrm{Ta} \geq 10, \mathrm{Tv}<5$, phosphate fixation $<2.5$ at $1.5-3$ years of follow-up after treatment (stage 4; LR- 3.39, LR+ 2.48, LR2.00 and LR- 1.88 , respectively).

The high activity of NAG and $\beta$-Gal confirms the active participation of renal tubules in pathological process in NS. Nevertheless the high enzymes level in the NS active stage before treatment (stage 1) was not necessarily indicate an unfavorable course of disease. Likelihood of NS progression increased while maintenance of uNAG activity $>50$ and $u \beta-G a l>30$ in $8-10$ weeks of therapy (stage $2 ; \mathrm{LR}+2.43$ and $\mathrm{LR}+2.29$, respectively); $u N A G>50$ and $u \beta-G a l>60$ in 6-9 months on tapering treatment period (stage 3; LR+ 1.96 and $\mathrm{LR}+2.81$, respectively); $\mathrm{uNAG}>17$ and $\mathrm{u} \beta-\mathrm{Gal}>30$ during $1,5-3$ years of follow-up after treatment withdrawal (stage 4; $\mathrm{LR}+1.79$ and $\mathrm{LR}+3.48$, respectively)

The detected prognostic intervals at different NS stage have enabled to initiate the prediction System of the unfavorable disease course based on the cascade principle (an ordered series of study steps) and parallel investigations of various parameters (several markers) at the same time (parallel studies) [2]. The RSG and enzymuric fragments of the multimarker parallel cascade System for prediction unfavorable NS course has been created (Fig. 1).

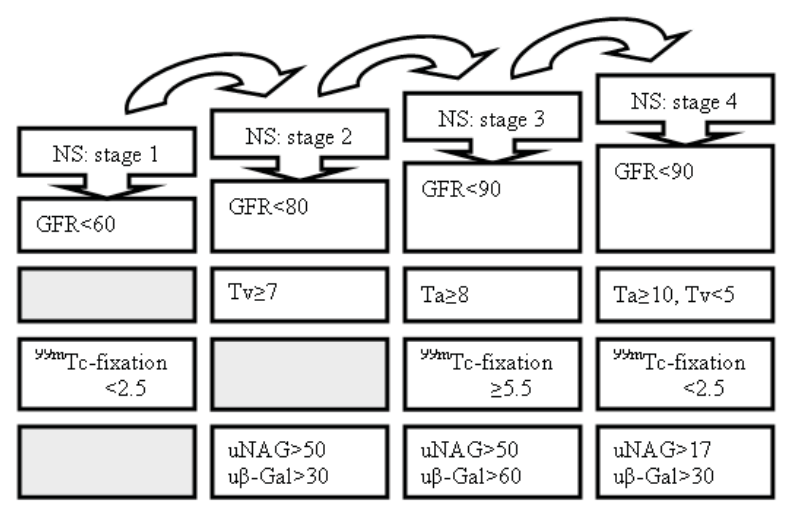

Fig. 1. The multimarker parallel cascade System for prediction unfavourable NS course in children (NS nephrotic syndrome; stage 1 before prednisolone treatment; stage 2 in 10 weeks of therapy; stage 3 on tapering treatment period 6-9 months; stage 4 1.5-3 years of follow up; GFR Glomerular Filtration

Rate (99mTc-DTPA); Tv venous flow duration (99mTc-

DTPA); Ta arterial flow duration (99mTc-DTPA); uNAG urine activity of $\mathrm{N}$-acethyl-( $\beta$-D- glucosaminidase; $\mathrm{u} / \beta-\mathrm{Gal}$ urine activity of $\beta$-galactosidase); gray box: parameter change does not have prognostic value. 
CONCLUSION. RSG indexes and urine enzymes activity should be used as markers of the progression in NS children as summarized in the proposed prediction System. The multimarker parallel cascade System for prediction of unfavorable NS course in children enables to identify the patients with a high risk of disease progression at any stage of observation, and to correct treatment programs. The benefits of proposed System are: it marks the optimal terms of examination and range of parameters; it authorizes to refuse obligatory serial studies; it based on available markers; it uses any available markers combination to confirm prognosis; probable outcome confirmed by the results a number of parallel investigations. This System is open: each stage of disease may be expanded by new suggestions and diagnostic tests. The multimarker parallel cascade System for prediction initiates a new strategic goal for determination of relevant unfavorable disease course parameters and it could be used in any branches of medicine.

\section{REFERENCES:}

1. Березин A. E. Клиническое и прогностическое значение биологических маркеров в стратификации пациентов с кардиоваскулярными заболеваниями (обзор литературы) / А. Е. Березин // Укр. мед. часопис. - 2010. - № 6 (80). С. 7985.

2. Фоміна С. П. Імунотропна терапія дітей, хворих на гломерулонефрит з нефротичним синдромом: автор. ... доктора мед. наук : 14.01.37 / С. П. Фоміна. - K., 2013. - 36 с.

3. Фоміна С. П. Маркери прогресування нефротичного синдромому у дітей / С. П. Фоміна // Педіатрія, акушерство та гінекологія. - 2012. № 6. - C. 22-25.
4. Фоміна С. П. Прогнозування несприятливого перебігу гломерулонефриту з нефротичним синдромом у дітей: ензимуричні маркери / С. П. Фоміна, І. В. Багдасарова, Л. Я. Мигаль // Український журнал нефрології та діалізу. 2013. - № 4. - С. 14-19.

5. Фомина С. П. Радионуклидные маркеры прогрессирования гломерулонефрита с нефротическим синдромом у детей / С. П. Фомина // Международный журнал педиатрии, акушерства и гинекологии. - 2012. - № 3. - С. 12-16.

6. Harmon W. E. Glomerular filtration rate in children with chronic kidney disease / W. E. Harmon // Clin. Chem. - 2009. - Vol. 55. - P. 400-401.

7. KT Clearinghouse [Електронний pecypc] / Canadian institute of health research, Centre for evidence-based medicine. Toronto, 2000-2011. Режим доступу : http://ktclearinghouse.ca/cebm/ practise/ca/

8. KDIGO Clinical practice guideline for glomerulonephritis // Kidney international supplements. 2012. - Vol. 2 (S. 2). - P. 139-274.

9. Lemley $K$. $V$. An introduction to biomarkers: applications to chronic kidney disease / K. V. Lemley // Pediatr. Nephrol. - 2007. - Vol. 22. - P. 18491859.

10. Tesch G. H. Review: serum and urine biomarkers of kidney disease: a pathophysiological perspective / G. H. Tesch // Nephrology. - 2010. - Vol. 15. P. 609-616.

Надійшла до редакції 27.08.2016 Прийнята до друку 02.08.2016

(C) Лавренчук О. В., Багдасарова I. В., 2016

УДК: 616.61/63-022.7-056

О. В. ЛАВРЕНЧУК, І. В. БАГДАСАРОВА

ОЦІНКА МІКРОБНОГО ПРОФІЛЮ ТА АНТИБАКТЕРІАЛЬНОӤ РЕЗИСТЕНТНОСТІ ЗБУДНИКІВ ІНФЕКЦІЇ СЕЧОВОЇ СИСТЕМИ У ДІТЕЙ МІСТА КИЕВА ТА ОБЛАСТІ

\author{
O. LAVRENCHUK, I. BAGDASAROVA
}

\title{
EVALUATION OF THE MICROBIAL PROFILE AND ANTIBIOTIC RESISTANCE OF BACTERIA CAUSING URINARY TRACT INFECTION IN THE CHILDREN OF KYIV REGION
}

Державна установа «Інститут нефрології НАМН України», м. Київ

SI "Institute of Nephrology NAMS of Ukraine", Kyiv

Ключові слова: інфекція сечової системи, діти, спектр уропатогенів, чутливість $і$ резистентність до антибактеріальних препаратів.

Key words: urinary tract infection, children, the

Лавренчук Ольга Василівна

lvi_lov@meta.ua spectrum of uropathogens, antimicrobial susceptibility and resistance.

Резюме. Швидке зростання набутої резистентності окремих штамів бактерій до антибакте- 